\title{
PROPOSED DEVELOPMENT MODELS OF ISLAMIC MOVEMENTS IN POST REFORMATION INDONESIA
}

Gonda Yumitro, Elfatih Abdullahi Abdelsalam and Syaza Farhana Mohamad Shukri

Universitas Muhammadiyah Malang, Jawa Timur, Indonesia International Islamic University of Malaysia International Islamic University of Malaysia email: gonda@umm.ac.id, elfatih@iium.edu.my, syazashukri@iium.edu.my

\begin{abstract}
This article tries to analyze the models of Islamic movements in post-reformation Indonesia. The major research problem posed is to highlight the main theoretical underpinnings of the momentum of reformation and its impact on various movements, particularly the Islamic ones. The focus here is to explain how these Islamic movements have developed strategies and models to face and circumvent the challenges. This is qualitative research that used documentary analysis and the Focused Group Discussion (FGD) in collecting information and data for analysis. In analyzing the data, the authors used Nvivo 12 Plus. This research found that the Islamic movements of Indonesia, in their quest for development and influence, have availed themselves of several developmental models, such as transnational and national Islamic movements, political and non-political movements, democratic and anti-democratic, and moderate and radical Islamic movements.

المللخص: تحملّ هذه المقالة فاذج الحركات الإسلامية في إندونيسيا بعد الإصلاح. تتمثل

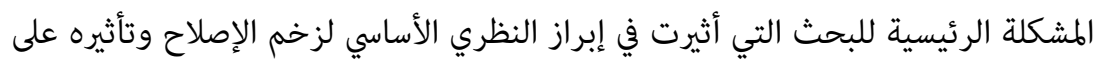

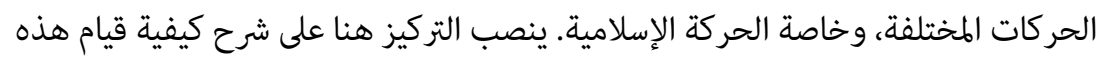

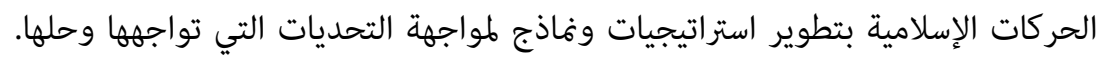

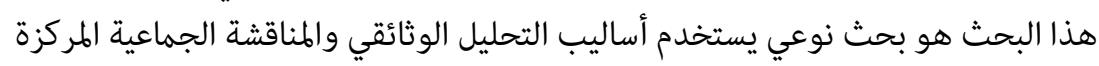

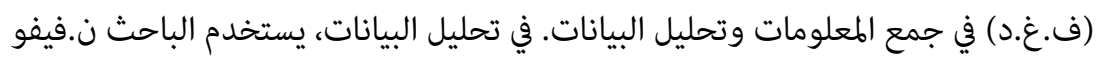


الب بلس. تتمثل النتائج الرئيسية لهذا البحث في أن الحركة الإسلامية في إندونيسيا استجابة

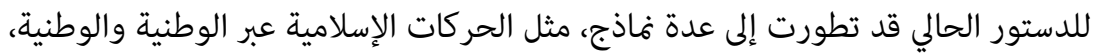

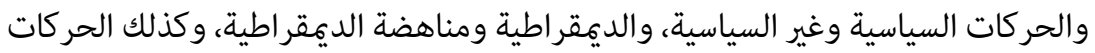
الإسلامية المعتدلة والمتطرّفة.

Abstrak: Artikel ini menganalisis model gerakan Islam pasca reformasi di Indonesia. Permasalahan utama penelitian yang dikemukakan adalah menyoroti landasan teori utama momentum reformasi dan dampaknya terhadap berbagai gerakan khususnya gerakan Islam. Fokus di sini adalah menjelaskan bagaimana gerakan-gerakan Islam tersebut mengembangkan strategi dan model untuk menghadapi dan menyelesaikan tantangan mereka hadapi. Penelitian ini merupakan penelitian kualitatif yang menggunakan metode documentary analysis dan Focused Group Discussion (FGD) dalam pengumpulan informasi dan analisis data. Dalam menganalisis data, penulis menggunakan Nvivo 12 Plus. Temuan utama dari penelitian ini adalah bahwa gerakan Islam di Indonesia dalam merespon konstilasi yang ada telah berkembang menjadi beberapa model, seperti gerakan Islam transnasional dan nasional, gerakan politik dan non-politik, demokrasi dan anti-demokrasi, serta gerakan Islam moderat dan radikal.

Keywords: development models, Islamic movements, reformation, Indonesia.

\section{INTRODUCTION}

The 1998 reformation has given the momentum for Islamic movements to exist and develop in Indonesian politics. Since that time, Indonesians have more freedom than they experienced during the Soeharto era. Vali Nasr stated that the reformation had caused military withdrawal from Indonesian politics since many people criticized Soeharto's policies as giving many strategic political positions to his military allies. Such a condition provided space for the Islamic movements to develop because the military was the biggest 
challenge to Islamic movements. ${ }^{1}$ Domestic and external factors influenced the development of Islamic movements in Indonesia. As for the domestic factors, political changes after the fall of Soeharto had inspired the emergence of Islamic da'wah movements, after building their limited networks during the New Order. At the end of Soeharto's tenure, the Indonesian Muslim Intellectuals Association (ICMI) was established, becoming the communication medium for Islamic groups with elites of the New Order. At that time, ICMI had a close relationship with the government because Habibie was one of the president's closest allies. ${ }^{2}$

In addition, external factors also played prominent roles in developing Islamic movements in post-reformation Indonesia since their notions had entered Indonesia before the reformation, such as Wahabism, Muslim Brotherhood, Jamaát Movements, and Shiism. ${ }^{3}$ Wahabism is closely related to Indonesian students who are close to the Islamic purification movements in Saudi Arabia. ${ }^{4}$ The Muslim Brotherhood movements were influenced by the large number of Indonesian students studying in Egypt. The Jama'at Movements emerged due to the strong connection of Indonesian Muslim activists to India and Pakistan. Lastly, Shiism has developed rapidly in Indonesia after the phenomenal 1979 Iranian revolution, which inspired some Indonesian intellectual groups. These transnational Islamic movements have penetrated Indonesia, and adapted to some local cultures.

With these two supporting factors, both internal and external, the Islamic movements got the opportunity to bring their existence to the reform era. For them, the crisis condition is an opportunity to offer alternatives to national problems, both in the social, cultural, economic, and political fields. Various arguments were built,

1 Vali Nasr, "The Rise of 'Muslim Democracy," Journal of Democracy 16, no. 2 (2015): 13-27, https://doi.org/10.4324/9781315682037.

2 Abdul Haris Fatgehipon, "The Relationship Amongst Soeharto, Military, and Muslim in the End of New Order Regime," Paramita: Historical Studies Journal 26, no. 1 (2016): 1, https://doi.org/10.15294/paramita.v26i1.5141.

3 Gonda Yumitro, "Partai Islam Dalam Dinamika Demokrasi Di Indonesia," Jurnal Ilmu Sosial Dan Ilmu Politik 17, no. 1 (2013): 42, https://doi.org/https://doi. org/10.22146/jsp.10892.

4 Noorhaidi Hasan, "The Failure of the Wahhabi Campaign Transnational Islam and the Salafi Madrasa in Post-9/11 Indonesia," South East Asia Research 18, no. 4 (2010): 675-705, https://doi.org/10.5367/sear.2010.0015. 
especially to bring Islamic values to the Muslim majority society. During the New Order era, the Suharto regime was considered to be discriminative against Islamic groups for a long time.

Furthermore, in terms of culture, Is 1 am has become a "pop culture" in society, with thousands of places of worship starting to get crowded, many women wearing the hijab, and standard greeting conveyed by assalamu 'alaikum (Peace be upon you) among the people. ${ }^{5}$ Meanwhile, in the economic sector, Islam can provide a sense of justice because the liberal economic system have created apparent social gaps within society. In Islam, the exploitation of the rich against the poor must be eliminated.

In the political sense, public support toward Islamic parties had also increased. The support influenced many domestic political issues; for example, some regions implements Islamic law such as Aceh, Bulukumba in South Sulawesi, Padang, and Tangerang. As a special region, Aceh implemented Islamic law by imposing rajam punishment (throwing stones to the w rongdoer until death) for those who conducted Zina (sexual int ercourse out of marriage). In Bulukumba, since 1998, the Regent has launched an intensive program of learning the Al Qur'an in various institutions such as mosques and Islamic schools. Moreover, government services are only provided to those who wear Islamic clothing. In Padang, all female students are required to wear hijab, while in Tangerang, prostitution sites were closed. ${ }^{6}$

During these conditions, several Muslim figures representing the movement's mainstream groups emerged, such as Amien Rais, Gus Dur, Hidayat Nur Wahid, and Habibie. These figures, given their strategic public positions, are inseparable from their Islamic background.

However, in its development, the Islamic movements faced various problems determining their future in public life in Indonesia, both related to internal and external problems. Thus, various Islamic movements confronted the specter of perfecting one or more

5 Ken Miichi, "Democratization and 'Failure' of Islamic Parties in Indonesia," in Southeast Asian Muslims in the Era of Globalization (London: Palgrave Macmillan, 2015), 127-44, https://doi.org/https://doi.org/10.1057/9781137436818_7.

6 Robin Bush, "Regional Sharia Regulations in Indonesia: Anomaly or Symptom?," Expressing Islam: Religious Life and Politics in Indonesia, no. March 2007 (2008): 174-91. 
developmental models in order to augment their chances of survival in order to influence the state and society vis-a-vis their adversaries. Hence, the main purpose of this article is to explore some of the major development models which have been adopted by Islamic movements in post-reformation Indonesia. This understanding of the development models of Islamic movements is crucial to portray the development and the future of political Islam in post-reformation Indonesia. For that purpose, the research question of this article is, what are the proposed development models of Islamic movements in post-reformation Indonesia?. Before exploring the finding of this research, the authors describe the Islamic movements and global and national contexts in the literature review.

\section{METHODOLOGY}

To answer the research question, this study was conducted using qualitative approach through document analysis and focus group discussions (FGD) as data collection methods. The authors reviewed a number of literatures, including books, articles, research notes, and other forms of databases available online. Following that, some of the major findings were discussed with the interviewees in the FGDs conducted on a convenience basis with a selection of social sciences scholars and Islamic activists who have been derived from various backgrounds, such as the elites of PKS (Prosperous Justice Party), PBB (the Crescent Star Party), PKB (Nation Awakening Party), PAN (National Mandate Party), PPP (the United Development Party), Muhammadiyah, NU (Nahdatul Ulama), Salafism, HTI (Hizbuttahrir Indonesia), Jama' ah Tabligh, and MIUMI (Indonesian Young Ulama Intellectual Council).

These interview processes were conducted in the area of Malang city, Malang regency, and Batu city. Those informants represented the scholars and Islamic movement at the national level since these regions consist of many people from various places of Indonesia to study and stay. Such condition is supported by the existence of these areas as the education and tourism cities. The Data collected were classified, reduced, and analyzed using Nvivo 12 plus. The authors used the coding and crosstab facility in Nvivo 12 plus to analyze the data. 


\section{LITERATURE REVIEWS: Islamic Movements in A Global and National Context}

Understanding the position of Islam in a global context is necessary to explain the issue of Islamic movements. So far, Muslim population has grown significantly, with a total of around 1.8 billion or at least $24 \%$ of the total population on earth in 2015 . $^{7}$ This condition may indicate that Islam had penetrated into various layers of societies with different cultures and backgrounds. However, Muslims are bound to understand that all Muslims throughout the world are brothers and sisters in faith and are not merely unified by the territory.

Meanwhile, in the political context, the Islam lacks of domintation as secular governments lead most countries. It led to the perception that the religious spirit had been marginalized by the secular structure of the modern country. ${ }^{8}$ Moreover, most Islamic countries had been influenced by the colonization they have experienced over centuries. Therefore, Islamic activists felt they were being mistreated and tried to find the Islamic identity to influence the life of the community. They believe that Islam is the solution to all problems, and Islamic values will bring justice within society. ${ }^{9}$ This belief became the inspiration and forerunner to the emergence of Islamic movements.

In the context of Indonesia, Muslims account for $85 \%$ of 265 million total populations making Indonesia the largest Muslim country in the world. Even though most people do not want Indonesia to be an Islamic state, they believe that the values of Islam must be practiced in everyday life. The government should be friendly to Islam and should not use violence and coercion to hurt the people's right to freedom of religion. ${ }^{10}$

7 W. S. Jatiningrum and A. Y. Astuti, "Theorizing of Spirit 212 in Predicting Muslim Behavioral Intentions: A Hypothesized Model," IOP Conference Series: Materials Science and Engineering 403, no. 1 (2018), https://doi.org/10.1088/1757899X/403/1/012047.

${ }^{8}$ Lisa Blaydes and Drew A. Linzer, "Elite Competition, Religiosity, and AntiAmericanism in the Islamic World," American Political Science Review 106, no. 2 (2012): 225-43, https://doi.org/10.1017/S0003055412000135.

9 Kunal Mukherjee, "Islamic Revivalism and Politics in Contemporary Pakistan," Journal of Developing Societies 26, no. 3 (2010): 329-53, https://doi. org/10.1177/0169796X1002600303.

${ }^{10}$ Delmus Puneri Salim, The Transnational and the Local in the Politics of Islam, The Transnational and the Local in the Politics of Islam, 2015, https://doi. org/10.1007/978-3-319-15413-8. 
Also, Islam in Indonesia has become an integral part of Indonesian culture. Moreover, Islam has marked a long history among the society due to the existence of some Islamic kingdoms in Indonesia, such as Perlak, Demak, Samudra Pasai, Mataram, Banten, Cirebon, Banjar, and Ternate Tidore. ${ }^{11}$ However, in its development, the culture of the community began to be eroded by various external influences and globalization. Therefore, various Islamic movements in Indonesia try to present Islam as a solution to respond to various global challenges in the modern era, such as poverty, unemployment, and terrorism. ${ }^{12}$

However, before the reformation, the space for freedom of Muslims to express their interests by carrying the spirit of Islam was still limited. The existence of Islam is more a political tool to strengthen the regime's legitimacy alone. They exist as an organization, for example, seen from the institutional existence of the United Development Party (PPP) and the Indonesian Muslim Intellectuals Association (ICMI). However, they failed to be effective media to fight for the interests of Muslims, especially those related to political issues. Moreover, several Islamic movements, including ICMI, received negative views as a group that intends to change the shape of the Indonesian state into an Islamic state, or a state system that applies Islamic law. ${ }^{13}$

Such suspicions neglected significant roles of Islamic movements during the independence of Indonesia. Islamic scholars (ulama) mobilized the people to oppose colonialism using the spirit of jihad. Moreover, at the beginning of the New Order, Soeharto attracted the sympathy of Muslims due to his role in combating communism, which opposed the existence of God and religion. However, after gaining his strength, the New Order regime tended to ignore and disregardthe Muslim groups. Kikue Hamayotsu explained that the

${ }^{11}$ Yumitro, "Partai Islam Dalam Dinamika Demokrasi Di Indonesia," 42.

${ }^{12}$ Ris'An Rusli et al., "Reactualization of Intellectualism in Classical Islamic Thought in Indonesia: Comparative Study of Muhammadiyah and Nahdlatul Ulama Post Reformation," Utopia y Praxis Latinoamericana 25, no. Extra1 (2020): 249-59, https://doi.org/10.5281/zenodo.3774635.

${ }^{13}$ Riki Rahman and Faisal S. Hazis, "ICMI and Its Roles in the Development of the Middle Class Muslim Communities in Indonesia in the New Order Era," AlJami'ah 56, no. 2 (2018): 341-66, https://doi.org/10.14421/ajis.2018.562.341-366. 
political character of Indonesia in the New Order was "anti-Islamic" and saw the west as an essential alliance. ${ }^{14}$

In post-reformation Indonesia, there is a widely open opportunity for Indonesian people and the Islamic movements to get involved in politics, to assemble political movements, and to think about politics. Islamic activists who had previously been involved in efforts to bring down Soeharto tried to institutionalize their movements. ${ }^{15}$ Since then, various transnational Islamic movements, political parties, and teachings that integrate with local culture have proliferated. As a plural society, Indonesian people appreciate differences. Therefore, the Islamic movements are concerned with the principles of tolerance in order to maintain peace in the community. ${ }^{16}$

In this case, it is understood that the political dynamics are influenced by several aspects, such as the state, community groups, local issues, political parties, political and social issues of society. However, the level of their influences is different. This data was obtained based on the Nvivo 12 plus analysis of the various views of social and political scholars in their publications (figure 1). In the issue of Islamic movements in post-reformation Indonesia, it was found that political and local issues have a significant influence on the discourse of the Islamic movement. Meanwhile, social issues and the existence of political parties have limited roles, and state and community groups tend to play passive roles because of their manifestation as the affected institution by the development of political issues.

${ }^{14}$ Kikue Hamayotsu, "Islam and Nation Building in Southeast Asia : Malaysia and Indonesia in Comparative," Pacific Affairs 75, no. 3 (2002): 353-75, https://doi. org/https://doi.org/10.2307/4127290.

${ }^{15}$ Felix Heiduk, "Between a Rock and a Hard Place: Radical Islam in PostSuharto Indonesia," International Journal of Conflict and Violence 6, no. 1 (2012): 26-40, https://doi.org/10.4119/UNIBI/ijcv.191.

${ }^{16}$ Noorhaidi Hasan, "Salafism in Indonesia: Transnational Islam, Violent Activism, and Cultural Resistance," in Routledge Handbook of Contemporary Indonesia (Taylor and Francis, 2018), 1-18. 


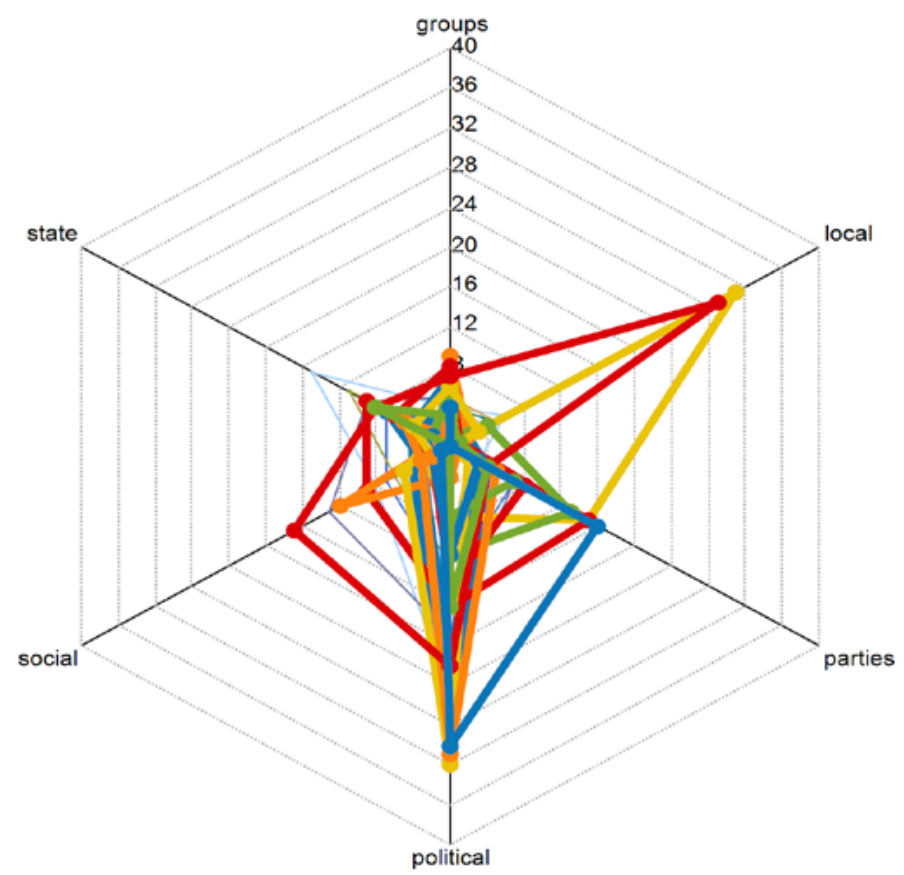

Figure 1. The aspect of Islamic Movements in Post Reformation Indonesia

\section{RESULTS AND DISCUSSION}

In this part, the authors explain the proposed development models of Islamic movements in post-reformation Indonesia. The model analysis is focused on variants and the relations among the Islamic movements. Simultaneously, the development of Islamic movements emphasizes on the dynamics of Islamic movements since the early era of reformation until today. This development encompassed when the Islamics had the opportunity to develop, rise, and decline since there were severe issues in Indonesian politics.

\section{THE DEVELOPMENT OF THE INDONESIAN ISLAMIC MOVEMENTS}

The Islamic movement in Indonesia had a great opportunity to develop after the reform. It was influenced by the desire of the people 
to reform the military group authoritarianism of the New Order. The presence of the Islamic movement is considered as a new alternative for them to treat their disappointment with the New Order regime, which was corrupt and ignored the interests of the broader community, especially those related to the needs of Muslims.

That momentum has been long-awaited and prepared by various Islamic movements since the era of the Soeharto regime by building underground networks with the Middle East link. Since the 1980s, Islamic student groups on campus have often carried out Islamic activities to prepare for their future cadres. Besides studying Islam, they also built awareness of the position of Muslims before the policies of the Soeharto regime, which at that time were considered repressive. At that time, they had discussed several political plans, including establishing an Islamic party. ${ }^{17}$ What they were looking for was the appropriate moment um to carry out their movements.

At the beginning of the reformation, many considered that this was the momentum for Islamic movements in Indonesia. The contradictions among the Islamic movement activists were not visible at that time. Although they were not a single entity and even conflicting with one another, some Islamic movements have links and similarities. They all believe in the truth of Islamic law, and even some wanted to implement it with different approaches.

The Islamic movements had developed rapidly during this era with the reinforcement of people's support. The political atmosphere at that time allowed various the Islamic movements to show their identities, organizational existence, and activities. It could be seen from the increasing number of Islamic schools, Islamic boarding schools, and the availability of various Islamic media such as websites, magazines, radio, and television.

Moreover, many people started to participate in various activities organized by the Islamic groups. However, some evidence indicated that most Islamic parties had a profound concern about developing religiosity in the community. It was also due to the lack of cooperation built with religious groups such as Muhammadiyah

${ }^{17}$ Ahmad Ali Nurdin, "The Influence of Middle Eastern Islamic Political Thought on Islamic Political Parties in Indonesia : The Case of PKS," Global Journal Al-Thaqafah 9, no. 3 (2019): 27-38. 
and NU. As a result, political parties lacked the maximum benefit to capitalize on the divine potential as their political tool. ${ }^{18}$

Nonetheless, activists of other Islamic movements continued to pump up their enthusiasm and looked for creative ways to attract public support and sympathy. Some Islamic movements had begun to develop Islamic concepts in approaching people's real problems. For example, it could be seen from various efforts to transform the values of Islam in politics, economics, social and cultural life, and make Islam as a foundation for people's morality. They believe that Islam cannot be separated from various aspects of life, including in the political context. ${ }^{19}$ The Islamic activists wanted to present Islam as $\mathrm{s}$ modern religion that could synergize material-world activities with the transcendental afterlife goals, and the role of Muslim scholars with scientists.

This spirit is also supported by the Islamic movement's cadre system, which has been going on quite systematically, especially since the reformation. Many of the alumni who studied in Islamic schools and pesantren have become Islamic activists. They do not only emerge as groups that understand the teachings of Islam based on Shari'a, but they have transformed into a model for new professional Muslim cadres. Thus, they began to influence various strategic sectors in society without carrying the appendage of Islamic shariatization in Indonesia directly.

\section{PROPOSED MODEL OF THE INDONESIAN ISLAMIC MOVEMENTS}

Understanding the Islamic movement in Indonesia cannot be based solely on a single perspective but need to be seen from various dimensions, such as social, political, and cultural aspects. Through the analysis using Nvivo 12 Plus tool, the various models of political Islam in Indonesia can be categorized as the following explanation.

${ }^{18}$ Jacqueline Hicks, "The Missing Link: Explaining the Political Mobilisation of Islam in Indonesia," Journal of Contemporary Asia 42, no. 1 (November 16, 2012): 39-66, https://doi.org/10.1080/00472336.2012.634640.

${ }^{19}$ Anton Minardi, "The New Islamic Revivalism in Indonesia Accommodationist and Confrontationist," Journal of Indonesian Islam 12, no. 2 (2018): 247-64, https:// doi.org/10.15642/JIIS.2018.12.2.247-264. 
Tabel 1.

The Proposed Models of Islamic Movement in Indonesia (Nvivo 12 Plus)

\begin{tabular}{llll}
\hline- No & - Name & - Ideological Movements & - The Models of Islamic Movements \\
\hline-1 & - Salafi & - Anti Democracy & - Transnational Movements/Radical \\
-2 & - HTI & - Anti Democracy & - Transnational Movements / Radical \\
-3 & - JT & - Anti Politics & - Transnational Movements/Moderate \\
-4 & - Muh & - Progressive & - Modern/Moderate \\
-5 & - NU & - Culturalist & - Traditional/Moderate \\
-6 & - PKS & - Islamic Democratic & - Islamic Political Parties/Moderate \\
-7 & - PKB & - Islamic Nationalist & - Islamic Political Parties/Moderate \\
-8 & - PBB & - Islamic Democratic & - Islamic Political Parties/Moderate \\
-9 & - PPP & - Islamic Democratic & - Islamic Political Parties/Moderate \\
-10 & - PAN & - Islamic Nationalist & - Islamic Political Parties/Moderate \\
-11 & - JIL & - Liberalism & - Intellectual Groups/Moderate \\
-12 & - JIMM & - Liberalism & - Intellectual Groups/Moderate \\
-13 & - MIUMI & - Conservative & - Intellectual Groups/Moderate \\
\hline
\end{tabular}

In other words, those movements can be categorized as transnational and national Islamic movements, political and nonpolitical movements, democratic and anti-democratic, and moderate and radical Islamic movements. The description of various models of Islamic movements in post-reformation Indonesia can be described as follows:

First, transnational and national Islamic movements. The transnational Islamic movement means that there is a group of Islamic movements that have a network of ideologies and movements that move across countries. Usually, they are united by the spirit of building the ummah and brotherhood among Muslims throughout the world. ${ }^{20}$ This movement is proliferating, supported by a globalized infrastructure that connects various parts of the world, being as like without distance. ${ }^{21}$ Among these transnational Islamic movements are the Muslim Brotherhood (IM), Salafis, Hizbuttahrir Indonesia (HTI), and Jama'ah Tabligh.

${ }^{20}$ Karen Leonard, "Transnational and Cosmopolitan Forms of Islam in the West," Harvard Middle Eastern and Islamic Review 8 (2009): 190-91.

${ }^{21}$ Peter Van Der Veer, "Transnational Religion; Hindu and Muslim Movements," Journal for the Study of Religions and Ideologies 3, no. 7 (2004): 101, https://doi. org/10.1111/1471-0374.00030. 
Meanwhile, the national Islamic movements are all Islamic movements that develop based on the locality of Indonesian society, without having a relationship with Islamic movements in other countries. National Islamic movements include Nahdatul Ulama (NU), often referred to as the traditionalist movement, and Muhammadiyah, which is often called the modernist movement.

Second, the political and non-political Islamic movements. The political movements mean that the groups have political intentions, either through formal or nonformal institutions. Those who believe in the formal institution consisted of political parties, such as PKS, PKB, PBB, PPP, and PAN. Other groups also have political goals, but they do not want to participate in the political system because they reject the democratic system. FPI (Front Pembela Islam), HTI (Hizbut Tahrir Indonesia), FKAWJ (Forum Komunikasi Ahlussunnah Wal Jama'ah), Laskar Jihad (LJ), and Majelis Mujahidin Indonesia (MMI) are the variants of these Islamic Movements. ${ }^{22}$ Meanwhile, Muhammadiyah, NU, ICMI, and Jama'ah Tabligh (JT) were more concerned with education and social activities.

On top of that, intellectual groups are among the examples of groups that do not clearly state their political orientation. During its development, this group is divided into liberal groups and conservative groups. For liberal groups, Islam is not an ideology. Therefore, they believe that implementing Islamic law through political parties is a utopian dream. ${ }^{23}$ JIMM and JIL represent this group. For them, Islam needs to present itself elegantly in a heterogeneous society by fostering reinterpretations of various Islamic teachings. They spread this idea through various media such as books and websites. ${ }^{24}$

For conservative groups, because Islam is an ideology, all aspects of life are necessary to uphold Islamic ideology. The implementation of Islamic law is critical. This idea is sounded by the Indonesian

${ }^{22}$ Firman Noor, "Comparison of The Political Perceptions Between Radical Islam and Moderate Islam in Indonesia in The Reform Era," Jurnal Penelitian Politik 2, no. 1 (2005): 13-33, https://doi.org/https://doi.org/10.14203/jpp.v2i1.389.

${ }^{23}$ Yon Machmudi, "Jemaah Tarbiyah and Islamisation in Indonesia," in Islamising Indonesia (Australia: ANU Press, 2008), 51-80, https://www.jstor.org/ stable/j.ctt24hddh.10\%0AJSTOR.

${ }^{24}$ Ahmad Ali Nurdin, "Islam and State: A Study of the Liberal Islamic Network in Indonesia, 1999-2004," New Zealand Journal of Asian Studies 7, no. 2 (2005): 30, http://iicas.org/libr_en/islst/libr_14_06_03_1is.htm. 
Young Intellectuals and Ulama Council (MIUMI), which opposes liberal idea.

Third, democratic and anti-democratic. The democratization developed in recent decades has also had a significant influence on the Islamic movement in Indonesia. Some groups argue that Islam is compatible with democracy, while others believe that Islam cannot work with democracy. Some groups accept democracy that ultimately adopts western democracy, but some think that there is a need to develop a theocratic democracy to provide space for Islam in democracy. In the history of Indonesian politics, Muhammad Natsir developed the idea of theocratic democracy. ${ }^{25}$

The supporters of democracy argue that democracy is not only good for secular human life but also benefits for the spiritual dimension of life. ${ }^{26}$ Some of the Islamic parties that emerged and developed after the reforms included PKS (Prosperous Justice Party), PKB (Nation Awakening Party), PBB (the Crescent Star Party), PPP (United Development Party), and PAN (National Mandate Party).

The presence of Islamic parties in Indonesian politics enriches the study of political parties in Indonesia. With the status of Indonesia as a Muslim majority country, the issue of Islam in Indonesia has attracted various parties using the Islamic proposition and symbol to gain public support. Based on the results of the Nvivo 12 analysis towards the discussions among the scholars of social and political science, there are three major groups of political parties, namely the Islamic party, the nationalist party, and the secular party. Interestingly, the nationalist party sometimes became very close to a secular party, and in a certain momentum, emerged as Islamic nationalists (see figure 2). The development of political discourses influenced the consideration of their political choices.

These different colors of movements influenced the ideal goals of the country they wanted to achieve. Each group felt that the form of the country with the ideological background they possessed was ideal. Some Islamic movements wanted to establish an Islamic state; nationalist groups supported the existence of a national state,

${ }^{25}$ Luthfi Assyaukanie, "Democracy and the Islamic State: Muslim Arguments for Political Change in Indonesia," Copenhagen Journal of Asian Studies 20, no. 20 SPEC. ISS. (2004): 36, https://doi.org/10.22439/cjas.v20i0.33.

${ }^{26}$ Assyaukanie, 39. 
while secular groups argued that religion should not enter the public sphere of life in Indonesia (See figure 2).

\section{Figure 2. Kinds of Political Parties in Post Reformation Indonesia}

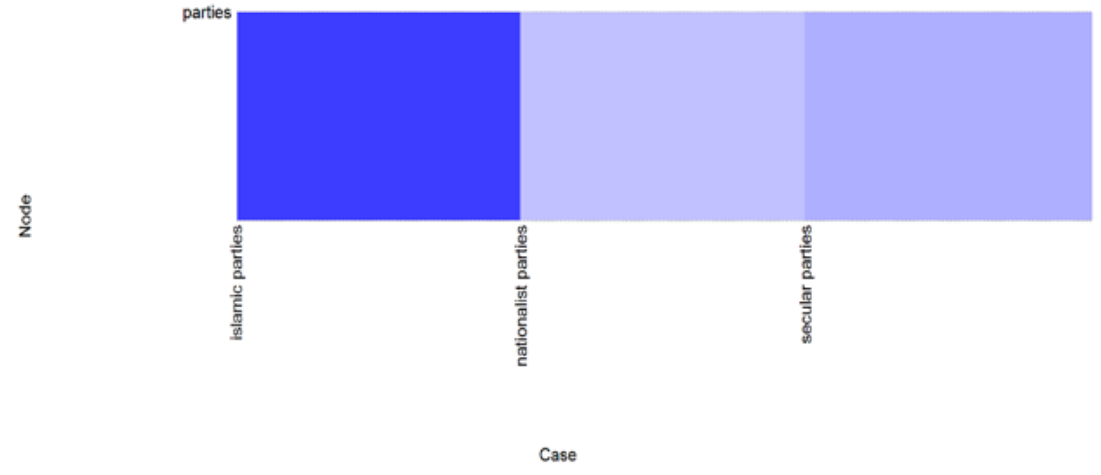

Figure 3. The Debates on Three State Forms of Indonesia

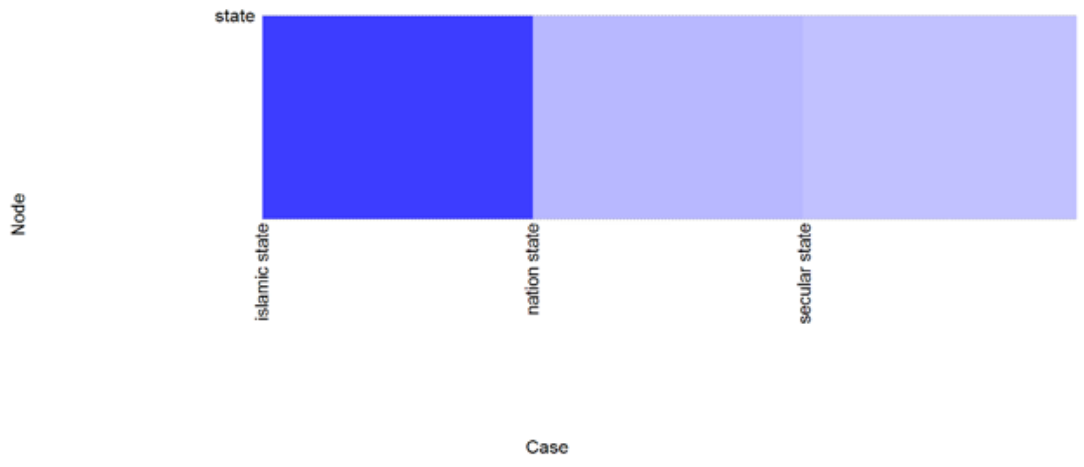

Meanwhile, anti-democratic groups are partly focused on preaching and education activities, such as Salafism. Some others carry out political activities in order to fight against democracy, such as HTI.

Fouth, moderate and radical Islamic movements. Various data indicated that most Indonesians support moderate groups of Islamic movements. It can be observed by seeing the development of various Islamic organizations and parties which show limited militancy to Islam. However, their activities and agendas are explicitly fighting for Islamic interests and agendas, such as demands for religious freedom and political representation. On the other hand, even though 
their number is limited, radical Islamic groups often use violence, inviting public attention.

Islamic movements can be measured by several variables, namely religious sentiments, Islamic identity and beliefs, enthusiasm for implementing Islamic law, and the development of Islamic schools and mosques. However, the use of violence by radical Islamic movements has made some people identify movements as the act of terrorist groups, using the name of Islam.

The problems are not only because of the radical groups. Even among the moderate groups, some of the Islamic groups are not necessarily able to run smoothly in achieving their interests. For example, PKS, as a party that adopts the ideology and strategy of the Muslim Brotherhood movements in Egypt, ${ }^{27}$ some people argue that it has a secret mission towards their acceptance of democracy. PKS is considered following the democratic process toward Islamisation through this path. Since some years ago, PKS has declared itself as an inclusive party. However, the suspicions towards this party still exist.

Therefore, PKS is in an awkward condition to strengthen its position in Indonesian politics. PKS wants to show itself as a professional party that can compromise with various groups of society, but at the same time, there is the demand for its commitment to Islamic ideological values. ${ }^{28}$ This becomes problematic when PKS lost its ideological roots to prioritize its political interests. In addition, with the fact that some elites were involved in corruption cases, the allegations that PKS is a less commitment party to Islam have strengthened. This condition was worsened by PKS efforts to become an inclusive party by accepting non-Muslims as party members. ${ }^{29}$

While moderate Islamic movements still draw suspicion and rejection from some people, the more challenging conditions were experienced by radical Islamic groups. During the discussion

${ }^{27}$ Anthony Bubalo, Greg Fealy, and Whit Mason, Zealous Democrats: Islamism and Democracy in Egypt, Indonesia and Turkey (Lowy Institute for International Policy, 2008).

${ }^{28}$ Bubalo, Fealy, and Mason.

${ }^{29}$ Vedi R Hadiz, "No Turkish Delight: The Impasse of Islamic Party Politics in Indonesia," Indonesia, no. 92 (November 16, 2011): 1, https://doi.org/10.5728/ indonesia.92.0001. 
regarding radicalism in a seminar at UIN Malang held by the Pesantren Tebu Ireng Alumni Association, all speakers conveyed their opposition towards the radical Islamic movement. They argued that radicalism is a threat to the unity of the Republic of Indonesia. Therefore, various elements of society must unite against these radical groups. However, when interpreting the radical movement itself, some of them identified the characteristics only based on physical performance, and not on the ideological characteristics.

This fact has invigorated the potential of conflicts among the Islamic movements. On the one hand, religion has substantial value to build unity in society; on the other hand, it is considered to create division. In fact, religion was only used as a tool by those who have political and economic interests. ${ }^{30}$

\section{CONCLUSION}

Based on the above explanation, it can be concluded that Islamic movements in Indonesia had the opportunity to develop after Soeharto's authoritarian regime. At the beginning of the reformation, they had the same mission to make Islam a solution to various problems. However, those various Islamic movements have developed in different models, such as transnational and national Islamic movements, political and non-political movements, democratic and anti-democratic, and moderate and radical Islamic movements.

They have been struggling to collaborate and coordinate with each other. Moreover, various Islamic groups do not have real souliton for the problems in the society. Some Islamic groups seem to be so pragmatic that only use Islam as an instrument of their political interests. Such conditions created a less ideal circumstance for Islamic movements to grow in post-reformation Indonesia.

\section{ACKNOWLEDGEMENT}

The authors would like to thank the International Islamic University Malaysia and the University of Muhammadiyah Malang for supporting research to complete this article.

${ }^{30}$ Ahmad Tholabi Kharlie and M. Ridwan Kubis, "The Portrait of Policy on Religious Harmony after the Post Reformation in Indonesia," International Journal of Psychosocial Rehabilitation 24, no. 5 (2020): 2213-27, https://doi.org/10.37200/IJPR/ V24I5/PR201920. 


\section{REFERENCES}

Assyaukanie, Luthfi. "Democracy and the Islamic State: Muslim Arguments for Political Change in Indonesia." Copenhagen Journal of Asian Studies 20, no. 20 SPEC. ISS. (2004): 32-46. https://doi.org/10.22439/cjas.v20i0.33.

Blaydes, Lisa, and Drew A. Linzer. "Elite Competition, Religiosity, and Anti-Americanism in the Islamic World." American Political Science Review 106, no. 2 (2012): 225-43. https://doi. org/10.1017/S0003055412000135.

Bubalo, Anthony, Greg Fealy, and Whit Mason. Zealous Democrats: Islamism and Democracy in Egypt, Indonesia and Turkey. Lowy Institute for International Policy, 2008.

Bush, Robin. "Regional Sharia Regulations in Indonesia: Anomaly or Symptom?" Expressing Islam: Religious Life and Politics in Indonesia, no. March 2007 (2008): 174-91.

Fatgehipon, Abdul Haris. "The Relationship Amongst Soeharto, Military, and Muslim in the End of New Order Regime." Paramita: Historical Studies Journal 26, no. 1 (2016): 1. https:// doi.org/10.15294/paramita.v26i1.5141.

Hadiz, Vedi R. "No Turkish Delight: The Impasse of Islamic Party Politics in Indonesia." Indonesia, no. 92 (November 16, 2011): 1. https://doi.org/10.5728/indonesia.92.0001.

Hamayotsu, Kikue. "Islam and Nation Building in Southeast Asia: Malaysia and Indonesia in Comparative." Pacific Affairs 75, no. 3 (2002): 353-75. https://doi.org/https://doi. org/10.2307/4127290.

Hasan, Noorhaidi. "Salafism in Indonesia: Transnational Islam, Violent Activism, and Cultural Resistance." In Routledge Handbook of Contemporary Indonesia, 1-18. Taylor and Francis, 2018.

. "The Failure of the Wahhabi Campaign Transnational Islam and the Salafi Madrasa in Post-9/11 Indonesia." South East Asia Research 18, no. 4 (2010): 675-705. https://doi. org/10.5367/sear.2010.0015. 
Heiduk, Felix. "Between a Rock and a Hard Place: Radical Islam in Post-Suharto Indonesia." International Journal of Conflict and Violence 6, no. 1 (2012): 26-40. https://doi.org/10.4119/ $\mathrm{UNIBI} / \mathrm{ijcv} .191$.

Hicks, Jacqueline. "The Missing Link: Explaining the Political Mobilisation of Islam in Indonesia." Journal of Contemporary Asia 42, no. 1 (November 16, 2012): 39-66. https://doi.org/10. 1080/00472336.2012.634640.

Jatiningrum, W. S., and A. Y. Astuti. "Theorizing of Spirit 212 in Predicting Muslim Behavioral Intentions: A Hypothesized Model." IOP Conference Series: Materials Science and Engineering 403, no. 1 (2018). https://doi.org/10.1088/1757899X/403/1/012047.

Kharlie, Ahmad Tholabi, and M. Ridwan Kubis. "The Portrait of Policy on Religious Harmony after the Post Reformation in Indonesia." International Journal of Psychosocial Rehabilitation 24, no. 5 (2020): 2213-27. https://doi.org/10.37200/IJPR/ V24I5/PR201920.

Leonard, Karen. "Transnational and Cosmopolitan Forms of Islam in the West." Harvard Middle Eastern and Islamic Review 8 (2009): 176-99.

Machmudi, Yon. "Jemaah Tarbiyah and Islamisation in Indonesia." In Islamising Indonesia, 51-80. Australia: ANU Press, 2008. https://www.jstor.org/stable/j.ctt24hddh.10\%0AJSTOR.

Miichi, Ken. "Democratization and 'Failure' of Islamic Parties in Indonesia." In Southeast Asian Muslims in the Era of Globalization, 127-44. London: Palgrave Macmillan, 2015. https://doi.org/https://doi.org/10.1057/9781137436818_7.

Minardi, Anton. "The New Islamic Revivalism in Indonesia Accommodationist and Confrontationist." Journal of Indonesian Islam 12, no. 2 (2018): 247-64. https://doi. org/10.15642/JIIS.2018.12.2.247-264.

Mukherjee, Kunal. "Islamic Revivalism and Politics in Contemporary Pakistan." Journal of Developing Societies 26, no. 3 (2010): 329-53. https://doi.org/10.1177/0169796X1002600303. 
Nasr, Vali. "The Rise of 'Muslim Democracy." Journal of Democracy 16, no. 2 (2015): 13-27. https://doi. org/10.4324/9781315682037.

Noor, Firman. "Comparison of The Political Perceptions Between Radical Islam and Moderate Islam in Indonesia in The Reform Era." Jurnal Penelitian Politik 2, no. 1 (2005): 13-33. https:// doi.org/https://doi.org/10.14203/jpp.v2i1.389.

Nurdin, Ahmad Ali. "Islam and State: A Study of the Liberal Islamic Network in Indonesia, 1999-2004." New Zealand Journal of Asian Studies 7, no. 2 (2005): 20-39. http://iicas.org/libr_en/ islst/libr_14_06_03_1is.htm.

. "The Influence of Middle Eastern Islamic Political Thought on Islamic Political Parties in Indonesia : The Case of PKS." Global Journal Al-Thaqafah 9, no. 3 (2019): 27-38.

Rahman, Riki, and Faisal S. Hazis. "ICMI and Its Roles in the Development of the Middle Class Muslim Communities in Indonesia in the New Order Era." Al-Jami'ah 56, no. 2 (2018): 341-66. https://doi.org/10.14421/ajis.2018.562.341-366.

Rusli, Ris'An, Toha Rudin, Candra Darmawan, and Ahlam Binti Ibrahim. "Reactualization of Intellectualism in Classical Islamic Thought in Indonesia: Comparative Study of Muhammadiyah and Nahdlatul Ulama Post Reformation." Utopia y Praxis Latinoamericana 25, no. Extral (2020): 249-59. https://doi. org/10.5281/zenodo. 3774635 .

Salim, Delmus Puneri. The Transnational and the Local in the Politics of Islam. The Transnational and the Local in the Politics of Islam, 2015. https://doi.org/10.1007/978-3-319-15413-8.

Veer, Peter Van Der. "Transnational Religion; Hindu and Muslim Movements." Journal for the Study of Religions and Ideologies 3, no. 7 (2004): 4-18. https://doi.org/10.1111/1471-0374.00030.

Yumitro, Gonda. "Partai Islam Dalam Dinamika Demokrasi Di Indonesia." Jurnal Ilmu Sosial Dan Ilmu Politik 17, no. 1 (2013): 35-50. https://doi.org/https://doi.org/10.22146/jsp.10892. 